\title{
SOUTHEAST EUROPE IN THE NEW GEOPOLITICAL CONTEXT
}

\author{
Antonina Habova \\ Assist. Prof. Dr., University of National and World Economy, Bulgaria, \\ antoninahabova@yahoo.com
}

\begin{abstract}
Against the background of tensions and destabilizing processes in different parts of the world a global geopolitical reshuffling is taking place. A new redistribution of economic and political power within the international system is in progress. There are changing roles of the major actors on the global scene, the emergence of new centers of power and new alliances.

The paper is aimed at analyzing the strategic and geopolitical importance of the Southeast European region for the major actors in the international system in the new geopolitical situation. In the context of the growing instability at the global and regional level and the renewed rivalry for influence and resources as well as in the context of the Ukrainian crisis and the developments in the Middle East, the SEE region is getting out of the geopolitical shadow and is back to the global chessboard as a particular geopolitical and geoeconomic zone.

The European Union, the United States, Russia but also China has different, often conflicting, interests in the region. All SEE countries (EU members and non-members) bind their future to the European Union. Still, there is an erosion of the hegemony of the European project itself. After a period of a relative disengagement from the region, the United States is putting back the region in the center of the US geopolitical attention. Russia - counting on the historic, cultural and political ties with the peoples in Southeast Europe - tries to further expand its economic and political influence in the region. China is the new actor in Southeast Europe. Chinese pro-active policy in this part of Europe is an integral component of "One Belt, One road" strategy, part of the strategic game of Beijing on the international chessboard aimed at gradually remodeling the existing world order.

The increased interest of the major powers towards the region adds further dynamism to the processes in the region itself. Any further intensification of the geopolitical rivalry between the great powers in the region could trigger new process of destabilization and fragmentation.
\end{abstract}

Keywords: Southeast Europe, geopolitical rivalry, global redistribution of power 


\section{INTRODUCTION}

Against the background of tensions and destabilizing processes in different parts of the world a global geopolitical reshuffling is taking place. A new redistribution of economic and political power within the international system is in progress. There are changing roles of the major actors on the global scene, the emergence of new centers of power and new alliances. These transformation processes are part of the transition to a new world order. Conflicts in different parts of the world (especially in geopolitically important zones) as well as the rising geopolitical tensions and confrontation are natural elements of any transition period.

This paper will analyze the intersection of interests and the rising confrontation in Southeast Europe after 2008 between four global actors - the United States as a world hegemon with diminishing power; the European Union with its ambitions to become a global geopolitical actor; Russia that is "back in the game"; and rising China. After a period of a relative disengagement from the region, the United States is putting back the region in the center of its geopolitical attention. The European Union tries to overcome its enlargement fatigue and to more steadily project its influence in this part of the continent. Russia - counting on the historic, cultural and political ties with the peoples in Southeast Europe - aims at further expanding its economic and political influence in the region. China is the new actor in Southeast Europe. Chinese proactive policy in this part of Europe is an integral component of "One Belt, One road" strategy, part of the strategic game of Beijing on the international chessboard aimed at gradually remodeling the existing world order.

According to some definitions Turkey is part of the term Southeast Europe. At the same time, Turkey enjoys an increased geopolitical significance at the beginning of the $21^{\text {st }}$ century. It follows an ambitious and multidimensional foreign policy doctrine with a specific focus on the Balkans, the Middle East and Central Asia. Turkey is a significant inter-regional power but still it is not a global actor. Hence, Turkey's policy towards the region, its underlying logic and motivation could be analyzed in a separate paper.

The year 2008 was an important moment both for the international system, the major powers as well as for the SEE regional system. In 2008 the world faced its most dangerous financial and economic crisis since the Great Depression of the 1930s with its strong implications for the United States as the global hegemon. The crisis had its political, identity, value dimensions for the EU. In Russia, this was the time when Dm. Medvedev took office and nominated Putin to be prime minister and when the military conflict between Russia and Georgia broke out. In the SEE region, Kosovo declared independence in February 2008 - a geopolitically important event as it created a precedent that could lead to redrawn borders in Europe and around the world and it openly challenged Russia's interests in the region (Stratfor, 2008). China, on the other hand, tried to use the crisis as an opportunity to promote its own commercial activity and to project influence in different parts of the world.

The notion of "Southeast Europe" has its political and geopolitical significance. It was always 'an alternative geographical identity for the Balkan region ever since it was first proposed in the late nineteenth century" (Gray and Sloan, 2013, p. 116). The term was first used by Austrian diplomat von Hahm in 1863. In 1999, under the initiative of the EU, the Stability Pact for Southeast Europe was launched. Albania, Bosnia and Herzegovina, Bulgaria, Croatia, Macedonia, Moldova, Montenegro, Romania and Serbia were defined as member partners from the SEE region. After the Thessaloniki summit in 2003, a new (narrower) political term was introduced - that of the "Western Balkans". It aimed at differentiating the countries in SEE according to their readiness to meet the EU membership criteria.

\section{GEOPOLITICAL SIGNIFICANCE OF SOUTHEAST EUROPE}

In the context of the growing instability at the global and regional level and the renewed rivalry for influence and resources as well as in the context of the Ukrainian crisis and the developments in the Middle East, the SEE region is getting out of the geopolitical shadow and is back to the global chessboard as a particular geopolitical and geoeconomic zone.

Against the background of the renewed East - West confrontation, the geopolitical significance of the SEE region is growing. Located between the East and the West, it is a convenient platform for projecting of economic, political, geopolitical and security interests in other geostrategically important regions such as Europe, Middle East, North Africa. It is also a significant point of intersection of different infrastructure corridors connecting Europe and Asia, Europe with the main sources on energy resources.

Because of its geographic middleness, the region is strongly affected by the geopolitical processes within the international system. In a period of turbulent changes in the international system internal dynamics in the 
region are shaped much more by external powers with their diverse interests than by regional actors and processes. On the other hand, the internal dynamic is largely determined by the existing fragmentation of the region along cultural, ethnic, religious, economic lines.

\section{THE UNITED STATES: KEEPER OF THE STATUS QUO}

After the end of the Cold war and the dissolution of the Soviet Union the West established a full dominance in Southeast Europe pushing out Russia from the region. The United States spread its influence in traditional Russia's allies such as Bulgaria and Romania. The post-Yugoslav status quo in the region was shaped primarily by the United States with the supporting role of its Western allies. They dictated the rules of peace after the wars related to the break-up of Yugoslavia. It was in an American air force base near Dayton where the peace agreement was reached putting an end to the Bosnian war. In Kosovo, the United States was directly engaged (including military) in the establishment of Kosovo Albanians' control over the territory of the former province of Serbia. The US military presence and geopolitical control in the region was cemented at the end of $20^{\text {th }}$ century with the establishment of the Bondsteel camp - one of the largest US military bases in Europe. Kosovo and Bosnia and Herzegovina are still much more Western protectorates than sovereign states as far as the existence of these states is due to the presence and control of international forces.

NATO, as an instrument for American influence, expanded deeply into the Southeast Europe which gets it closer to strategically important zones and new theaters of war. Bulgaria, Romania as well as Albania and Croatia are members of NATO. Because of the name dispute with Greece, Macedonia didn't become NATO full member in 2009. Matthew Nimetz - who is an American diplomat - is the UN Special Representative for the naming dispute between Greece and Macedonia. Bosnia and Herzegovina was granted Membership Action Plan in 2010.

Montenegro was also granted the Membership Action Plan in 2009 and was invited to join the Alliance in 2015. The invitation, extended in a period of tense relations between the West and Russia, will undoubtedly fuel further confrontation. Russia's position on NATO expansion to the East was articulated by Vladimir Putin in his landmark speech at the Munich security conference in 2007: "it is obvious that NATO expansion does not have any relation with the modernization of the Alliance itself or with ensuring security in Europe. On the contrary, it represents a serious provocation that reduces the level of mutual trust" (Putin, 2007). Russia's reaction to NATO invitation to Montenegro is even sharper - NATO decision was assessed as "openly confrontationist move which is fraught with additional destabilizing consequences for the system of EuroAtlantic security" (Ministry of Foreign Affairs of the Russian Federation, 2015).

The US military presence in the region was expanded in accordance with two agreements signed with Romania and Bulgaria. Under a Defense Cooperation Agreement signed between the United States and Romania in 2005, the latter hosted two US-Romanian joint facilities - Romanian Air Force's Mihail Kogălniceanu Airfield close to the Black sea port of Constanta and Romanian Land Forces Babadag Training Area. There are also Bulgarian-American Joint Military Facilities (two of them are air bases) established in Bulgaria by a Defense Cooperation Agreement signed by Bulgaria and the United States in April 2006. The bases in Romania and Bulgaria are under the US "lily pad" basing concept. Under this concept, instead of permanent, large-scale military installations in different countries, there would be a series of bases strung out across the world used as forward operating base in a time of crisis (BBC, 2004).

Black Sea Rotational Force was launched in 2010 with the aim to form a Security Cooperation Marine AirGround Task Force. It is a part of the U.S. European Command (EUCOM) and provides for military-tomilitary engagements with countries in Eastern Europe. The Black Sea Rotational Force is based at the Mihail Koglinceanu Air Base in Romania.

US military presence in Romania was further increased in 2013. In the height of the conflict in Ukraine, Romania allowed the U.S. military to use Mihail Kogalniceanu Air Base as a key logistics hub for getting supplies and troops in and out of Afghanistan as the Kyrgyz government refused to extend US lease at Manas airbase. An installation that is a component of a NATO's overall ballistic missile defense (BMD) system was deployed in the country in 2015 (Romania's Permanent Delegation to NATO, 2015). The Aegis BMD system, to which Russia is strongly opposed, is the key element in the US plan for a phased deployment of a missile defense umbrella in Europe.

The US Assistant Secretary of State for European and Eurasian Affairs Victoria Nuland urged NATO at the beginning of 2015 to install command and control centers in six Central and East European states (Lithuania, Latvia and Estonia, Poland, Romania, Bulgaria and possibly Hungary) defining them as "frontline countries". NATO command centers (NFIU - NATO Force Integration Units) were established seven months later in Bulgaria and Romania as well as in the rest of the CEE countries. This activity was criticized by 
Russia as a part of NATO efforts to strengthen Alliance's Eastern flank that would lead to escalation of confrontation (Permanent Mission of the Russian Federation too NATO, 2015). There are some speculations that Southeast Europe, with the assigned role of a frontline zone, could be an element of a cordon sanitaire around Russia that would further facilitate Europe's separation from Russia. This would help the United States to consolidate its influence in Eurasia.

The only two zones where the West did not obtain a full control were Serbia and, to some extent, Macedonia. Still, Serbia signed the Individual Partnership Action Plan (IPAP) with the Alliance in March 2015, which is the highest level of cooperation within the Partnership for Peace program. In Macedonia, the United States seized the opportunity provided by the increased tensions in 2001 and 3500 NATO troops were sent to the small republic "to disarm ethnic Albanian groups and destroy their weapons" - Operation "Essential Harvest" (NATO HQ Skopje, 2001). NATO military presence was prolonged twice - Operation Amber Fox (2001-2002) и Operation Allied Harmony (2002-2003) and then it was followed by an EU military operation.

The United States is the dominant external power in the region at the beginning of $21^{\text {st }}$ century. This allows it to focus its policy on other priority zones - 'Pivot to Asia', Middle East, financial crisis. The SEE region, however, does not fall out of the US geopolitical agenda. The United States keeps an open eye on the developments in the region preserving the status quo and reacting whenever it is challenged.

\section{THE EUROPEAN UNION}

The EU project enjoyed a full dominance in the SEE region after the end of the Cold war and the years of wars in the Western Balkans. All SEE countries binded their future with a membership in the Euro-Atlantic structures. The EU membership was seen as a mechanism for establishing stability, receiving the so needed resources and achieving development in that turbulent region. The European Union, on the other hand, provided for the SEE countries the membership perspective aiming at further expanding its influence to the east. Geopolitically, the EU enlargement process increases the legitimacy of the integration community. Theoretically, the bigger the EU is, the bigger EU sphere of influence and EU power in the international system is. The 'stick and carrot' approach, economic and bureaucratic mechanisms of control were the more effective instrument for the EU to guarantee stability in its periphery but also to secure the establishment of Western influence and Western rules of the geopolitical game in the region.

The EU had its role in the stabilization of the region. The Union has had its police and military missions both in Bosnia and Herzegovina (completed EUPM/BiH and ongoing EUFOR Althea) and in Macedonia (the first ever EU military mission EUFOR Concordia replaced by EUPOL PROXIMA/FYROM and then EUPAT). The EU is present also in Kosovo with its EU Rule of Law Mission (EULEX Kosovo) initiated in 2008 after Kosovo declaration of independence and operating under the umbrella of the UN Interim Administration Mission in Kosovo (UNMIK).

After the accession of Bulgaria and Romania to the EU in 2007, there was a relative enlargement fatigue and more reticent EU policy towards the SEE countries and any further enlargement of the Union. At the same time, the developments following the 2008 crisis have revealed that there is an erosion of the hegemony of the European project in the region and shrinking of the EU geopolitical position.

Starting recovering from the deep economic and financial crisis (but still facing the crisis of the European project itself), the EU tried to react to these challenges and revitalized and reinforced its enlargement policy. First, the Council launched the accession process of Montenegro in 2011 and the accession negotiations started in 2012. Second, Serbia received full candidate status in 2012. After the "tandem formula" of Bulgaria and Romania in their EU and NATO accession process, a new tandem was set up - between Serbia and Kosovo. The decision of the European Council to open EU membership negotiations with Serbia became possible after the Brussels Agreement of 2013 between Serbia and Kosovo considered as a major step towards normalizing relations. The High Representative for Foreign Affairs and Security Policy Catherine Ashton was personally involved in facilitating a High-Level Dialogue between Belgrade and Pristina. The first two chapters (on normalization of relations with Pristina and on financial control) in the negotiations were opened in December 2015. Third, Croatia joined the European Union in 2013. Following the formula 'first NATO, then EU', Albania became NATO member in 2009 and an official candidate for accession to the European Union in June 2014. Macedonia is a special case because of the already mentioned name dispute with Greece.

The re-intensification of the EU enlargement policy coincides not only with the process of EU recovery from the economic and financial crisis. It coincides also with the beginning of a period of deep transformations in the international system and a more active policy of the third countries in the SEE region. 


\section{RUSSIA'S GEOPOLITICAL COME-BACK}

After the end of the Cold war, Russia as a successor of the Soviet Union lost the initiative in the Southeast European region. Though it is a region where Russia traditionally had its presence, it was not able to counter the disintegration of Yugoslavia, NATO's 1999 operation against Serbian and did not take any overt action even against the independence of Kosovo.

After the period of a weakened Russia's geopolitical position in this part of Europe, there has been an evident activation of Russia's policy (especially in the second decade of the $21^{\text {st }}$ century) aimed at building influence in different SEE countries. This activation is related to the return of VI. Putin to Kremlin and its more confident and assertive foreign policy focused on restructuring of international relations and changing the rules of the game in the international system. This more assertive Russian policy in the region is stipulated in the Concept of the Foreign Policy of the Russian Federation, 2013: "The Balkan region is of great strategic importance to Russia, including its role as a major transportation and infrastructure hub used for supplying gas and oil to European countries".

Serbia is the major ally of Russia in the SEE region. It opened up negotiations to join the EU but at the same time its relations with Russia became even stronger in the last several years - a policy defined by some experts as balanced and, by others, as a paradox. In the economic sector, Russia is the second largest trade partner of Serbia after the EU (Directorate-General for Trade, European Commission, 2015). However, Serbia is the only one SEE country that has Free Trade Agreement with Russia signed in 2000.

Serbia hosts the first of its kind Russian-Serbian humanitarian center. Situated in the city of Nis, the center was inaugurated in 2011 and operates under the control of the Ministry of Emergency Situations of Russia and the Ministry of Internal Affairs of Serbia. The mission of the center (as declared on its website) is "to provide humanitarian emergency response in Serbia and other Balkan states". The declared regional scope of the future activities of the center as well as the very presence of Russians on the ground set a serious challenge to the US and EU interests in the region. There is some concern that the center could go beyond its humanitarian profile and function as a Russian military base.

The EU response came in April 2015 when Serbia and the European Union signed an agreement for Serbia's accession to the EU's Civil Protection Mechanism. The mechanism facilitates cooperation in disaster response, preparedness, and prevention among 32 European states (EU 28 plus Macedonia, Iceland, Norway and Montenegro) i.e. it has the same goals as those of the Russian-Serbian humanitarian center.

The year 2013 was a turning point in the relations between Russia and Serbia. The two countries signed two important documents - Declaration on strategic partnership and Agreement on Military Cooperation. In the same year Serbia, which declared military neutrality, became a permanent observer at the Collective Security Treaty Organization. Bilateral Serbian - Russian military cooperation was further enhanced in October 2015 when Serbian Prime Minister Aleksandar Vucic declared Serbia's decision to buy arms purchases from Russia in order to maintain a security balance in the region after Croatia bought new military hardware (Balkaninsight, October 28, 2015).

Serbian military unit marched at the victory parade in Moscow commemorating 70 years since victory over Nazi Germany in World War Two - an event that was boycotted by most EU leaders. Serbian troops participated in 2015 in joint military drill named "Slavic brotherhood", involving the Serbian, Russian and Belarus armies, which was assessed by EU officials as a "wrong signal" (EurActiv, August 15, 2015). The drill took place a few days after the conclusion of 'Swift Response' - the largest NATO airborne drills in Europe since the end of the Cold War across Germany, Italy, Bulgaria and Romania.

There has been an increased Russian interest in Macedonia. In addition to the intensified political dialogue between Moscow and Skopje, there is an increase in their trade and economic relations. The Macedonian President G. Ivanov has pointed out that further promotion of friendly relations with Russia remains a special interest of Macedonia (President of the Republic of Macedonia, February 3, 2014). Macedonia, Serbia and Bosnia and Herzegovina were the only SEE countries that did not join EU sanctions on Russia.

There was an accelerated growth of Russian investments and an increasing volume of foreign trade between Russia and the SEE countries in the last decade though the EU remains the major trading partner for all of them (Božić-Miljković, 2014). There is a strong Russian economic presence in Montenegro, for example, where Russia is one of the major investors (Montenegrin Investment Promotion Agency, 2015). Despite the strong economic ties, however, Russia is losing ground in this country. The Montenegrin leadership is firmly on the track to NATO membership and has even declined Moscow's request to establish a Russian military base at Bar (Torralba, 2014). 
Russia, however, preserves its own bridgehead in the SEE region. It is Transnistria that is situated between the Dniester River and the eastern border of Moldova with Ukraine and could serve as a fulcrum for Russian policy in the broader region.

\subsection{Energy Contest}

One of the most important strategic instruments used by Russia to build influence in the region is its energy policy. The EU and the United States as 'winners' of the Cold war, relied on the attractiveness of their model of development (perceived by them as universal) as well as on their enormous financial power. Russia relies primarily on its historic, cultural and political ties with the SEE peoples, on the common Slavic origin and shared Orthodox religion as well as on its enormous energy resources. The energy field is where the strategic competition between the external powers is particularly harsh in Southeast Europe. The region is strategically important in terms of the international projects for diversification of sources of energy resources and the transportation routes.

Russia is the major source of energy resources for the countries in the region. Russia supplies $100 \%$ of the consumed gas in Bosnia and Macedonia, $89 \%$, Bulgaria; $90 \%$, Serbia; $60 \%$ Slovenia, 56\%, Greece; $24 \%$, Romania (The Economist, 2014). The problem is even deeper as far as there is only one transit route from Russia to the SEE region - the one via Ukraine.

In order to reduce Europe's dependence on Russia's energy resource, the European Commission approved in 2008 the initiative for the establishment of a Southern energy corridor with Nabucco pipeline project as its keystone. Nabucco project, backed by the United States, would have brought gas from the Caspian region to Europe via Turkey, Bulgaria, Romania, Hungary and Austria. South Stream project was Russia's reaction to Nabucco project. The project's route would have started from Russia through the Black sea, Bulgaria, Serbia, Hungary and Slovenia further to Austria, with linking sections to Macedonia and Greece.

Both Nabucco and South Stream project were cancelled. Nabucco project was terminated after Shah Deniz consortium decision to prefer the Trans-Adriatic Pipeline (TAP) over Nabucco in 2013. The 2008 financial crisis, the lack of EU political will and of more active and focused policy towards the Caspian region were among the reasons for Nabucco's failure. South Stream project was cancelled at the end of 2014, as well. The vacillating position of the Bulgarian government was pointed out by the Russian President as the major reason for the suspension of the project. Bulgaria was under particular pressure by US and EU officials who declared the intergovernmental agreements signed between Russia and its six European partners in South Stream to be incompatible with EU competition law. South Stream project was then replaced by Turkish stream that was also suspended as a result of the deterioration of the Russian-Turkish relations in the autumn of 2015.

Two other strategic energy projects related to Russia were suspended by the authorities in Bulgaria under US/EU pressure - the project for the construction of a nuclear power plant with Russian technology and participation as well as the project for the construction of Burgas - Alexandroupolis oil pipeline. The oil pipeline project, bypassing the Turkish straits, was seen as a rival to the US-backed AMBO pipeline project from the Bulgarian Black sea port of Burgas to the Albanian port of Vlore via Macedonia. AMBO pipeline project was proposed in 1993 and Bulgaria, Macedonia and Albania signed a trilateral convention on the construction of the pipeline in 2007.

Russia's presence in the SEE energy sector is advanced also through investments in the oil and gas sector of the SEE countries. Gazprom Neft owns $56.15 \%$ of Serbia's oil monopoly Naftna Industrija Srbije (NIS). Gazprom owns $51 \%$ of the Banatski Dvor underground gas storage facility in Serbia. Russian company Lukoil owns the largest oil refinery in SEE - LUKOIL Neftochim Burgas, based in Burgas, Bulgaria as well as Petrotel Lukoil Refinery in Southern Romania. The only one oil refinery in Bosnia and Herzegovina Brod Oil Refinery and Modrica Motor Oil Plant were acquired by the Russian Zarubezhneft. Russian company Stroytransgaz is constructing the Klecovce - Negotino gas pipeline in Macedonia.

\section{CHINA: NEW ACTOR, NEW APPROACH}

China is a global actor with the potential to play a key role in the transformation process in the international system. After decades of passiveness and non-interference policy, China seems ready to apply a more assertive foreign policy approach and to seek advancement of its interests in different parts of the world.

After the end of the Cold war, China was focused on continuing its economic reforms. One part of the Southeast European countries was totally oriented towards the West pursuing Euro-Atlantic integration. The rest of the countries were dragged into wars. Things have started to change significantly after 2008 when China took advantage of the relative EU disengagement from the region and started its economic 
penetration.

China initiated the establishment of the Economic and Trade Forum of China-CEE countries (16+1 format) in 2011. Its Secretariat run by the Chinese Ministry of Foreign Affairs set up a credit line of USD 10 billion to support cooperative projects in 2012. Half of the participants in the forum are Southeast European countries - Albania, Bosnia and Herzegovina, Bulgaria, Croatia, Macedonia, Montenegro, Romania and Serbia. Kosovo is missing from the list as far as China does not recognize it as an independent state.

China takes into consideration the heterogeneity of the region and perceives ' $16+1$ ' initiative as a platform for further development of the bilateral relations between China and the CEE countries. The reaction of Brussels, however, was one of irritation and criticism. The initiative was assessed as an assault on the EU foreign policy unity and part of the Chinese plan for the expansion of its influence in Europe.

Chinese president Xi Jinping launched "One belt, one road" initiative - Silk Road Economic Belt plus $21^{\text {st }}$ Century Maritime Silk Road in 2013. The major dimensions of this new China's grand strategy, as defined by the Chinese president, are: policy communication; road connectivity from the Pacific to the Baltic Sea and the formation of a transportation network that connects East Asia, West Asia, and South Asia; trade facilitation; monetary circulation; people-to-people exchanges. The route of the Silk Road Economic Belt will pass through two of the SEE countries - Bulgaria and Romania.

The Southeast European region is important for Beijing because of its geographic and political proximity to Western Europe. "Chinese companies are clearly searching for an entry point into Europe and they see the region as an entry point into Europe," said Gabor Gion, Deloitte's Central Europe Chinese Services Group Leader, quoted by Reuters (Reuters, 2013). Chinese investments in the region are primarily in infrastructure, energy sector, agriculture. China put a particular focus on infrastructure connectivity between Europe and Asia and the development of a network of infrastructure facilities in the region is seen as a component of this major strategic aim of the Chinese leadership. Chinese companies have expressed interests and agreements have been signed on the following projects: project for the construction of rail line connecting Serbia and Montenegro; high-speed railway line between Belgrade and Budapest; high-speed railway Bucharest - Chisinau; reconstruction of a railway link between the port of Rijeka and the border with Hungary via Zagreb, etc.

In the energy sector, Chinese companies are interested in nuclear energy projects (Romania), in the construction/upgrading of thermal power plants (Serbia, Romania, Montenegro, Bosnia and Herzegovina), in the hydro potential of the SEE states (Macedonia, Bosnia and Herzegovina) as well as in the renewable energy sector (Bulgaria, Romania, Croatia).

Stepping on the understanding that enhanced communication brings about mutual development and enhanced capacity for meeting common challenges, Chinese approach towards the region is different from the Western one. China does not offer any membership perspective to the countries in the region. There is no 'stick and carrot' policy, no political or economic criteria. Chinese institutions offer the so needed for the SEE countries fresh investments, low-interest long-term loans to fund above $85 \%$ of a project in the cases when a Chinese company is a contractor. The ensuing economic penetration is a solid base for further projection of Chinese influence in this region.

\section{CONCLUSION}

Profound changes are taking place in the international system. There is an increased confrontation and competition for influence among powerful geopolitical actors both at the global and regional level. The Southeast Europe is exposed to these developments, as well. There is a new phase of geopolitical competition in the region where some external actors aspire to change the balance of powers established after the end of the Cold war and others that try to preserve it.

In this context, the Southeast European region faces two possible scenarios. The first scenario presumes a creeping evolutionary transformation while preserving the European integration as a priority. According to this scenario, the SEE countries will stick to their Euro-Atlantic integration and continue their attempts to 'westernize' themselves. The European Union itself, aware of the increasing importance of the region in the context of the Middle East crisis, the developments in North Africa, the refugee crisis as well as the penetrating influence of other external powers, will not turn its back to this part of the continent. The fear of further destabilization of the EU soft underbelly would stimulate Brussels to continue its enlargement process up the Southeastern part of the continent. This, however, could not happen without changes in the existing European architecture. The President of the European Commission Jean-Claude Juncker articulated it quite clearly on November 18, 2015: "One day we should rethink the European architecture with a group of countries that will do things, all things, together and others who will position themselves in an orbit different 
from the core" and "in the long term it will not be possible to have 33, 34, 35 Member States following the same speed and direction. One day it will be necessary to rethink the European architecture" (European Commission, 2015).

The second scenario assumes that there will be an activation of unresolved problems in the region based on the existing dissatisfaction with the status quo. Among the destabilizing factors that have the potential to undermine regional security is ethnic nationalism, the unstable situation in Bosnia and Herzegovina, the Albanian question, Macedonia, Transnistria, internal political and economic crisis as well as the refugee exodus in Europe. The increased interest of the major powers towards the region could add further dynamism to the existing problems in the region itself. Any further intensification of the geopolitical rivalry between the great powers in the region could trigger new process of destabilization and fragmentation.

The Southeast Europe is in the periphery of Europe but also in the periphery of Eurasia. This dual periphery (periphery + periphery) status could turn to be a center of crisis and conflicts that would throw the region again in the spiral of instability and insecurity with the respective spillover effect on the rest of the continent.

\section{REFERENCE LIST}

Božić-Miljković, I. (2014). Foreign trade between Russia and the Balkans in the context of global geostrategic relations. Journal of Globalization Studies, Vol. 5 No. 2.

Citizens' Dialogue in Brussels, Belgium. European Commission, 2015. http://ec.europa.eu/citizensdialogues/belgium/brussels/index_en.htm

Concept of the Foreign Policy of the Russian Federation, The Ministry of Foreign Affairs of the Russian Federation, 12 February 2013. http://www.mid.ru/brp 4.nsf/0/76389FEC168189ED44257B2E0039B16D

Conscious uncoupling. The Economist, Apr 5th 2014. http://www.economist.com/news/briefing/21600111reducing-europes-dependence-russian-gas-possiblebut-it-will-take-time-money-and-sustained

Directorate-General for Trade, European Commission (2015). European Union, Trade with Serbia. http://trade.ec.europa.eu/doclib/docs/2008/august/tradoc 140028.pdf

Gotev, G. (2015) EU says Serbian manoeuvres in Russia send 'wrong signal'. EurActiv, 18 Aug 2015. http://www.euractiv.com/sections/europes-east/eu-says-serbian-manoeuvres-russia-send-wrongsignal-316904

Gray, C., Sloan, G. (2013) Geopolitics, Geography and Strategy. Routledge.

Jovanovic, I. (2015). Serbia Buys Russian Arms, Joins NATO Drill. Balkan Insight,October 29, 2015. http://www.balkaninsight.com/en/article/serbia-tries-to-balance-between-west-and-russia-10-282015\#sthash.SmFCwvqo.dpuf

Ministry of Foreign Affairs of the Russian Federation (2015). Comment by the Information and Press Department on invitation for Montenegro to start talks on joining NATO. 2351-02-12-2015. http://en.mid.ru/en/web/guest/foreign_policy/news/-

/asset_publisher/cKNonkJE02Bw/content/id/1963259

Montenegrin Investment Promotion Agency (2015). FDI Statistics. Government of Montenegro. http://www.mipa.co.me/fdi_statistics.php

President of the Republic of Macedonia (2014). Relations with Russia are of Special Interest to Macedonia. ITAR - TASS, 03 February 2014. http://www.president.gov.mk/en/media-centre/in-the-media/2565itartass.html

President of Russia (2008). Speech and the Following Discussion at the Munich Conference on Security Policy. February 10, 2007.

http://archive.kremlin.ru/eng/speeches/2007/02/10/0138_type82912type82914type82917type84779_1 18123

Reynolds, P. (2004). US redeploying for quicker action. BBC News Online. http://news.bbc.co.uk/2/hi/americas/3569850.stm

Stratfor (2008). Kosovar Independence and the Russian Reaction. Geopolitical Weekly, February 20, 2008. https://www.stratfor.com/weekly/kosovar_independence_and_russian_reaction 
Torralba, R. M. (2014). Belgrade at the crossroads: Serbian-Russian relations in light of the Ukraine crisis. ARI 63/2014.

http://www.realinstitutoelcano.org/wps/portal/web/rielcano en/contenido?WCM GLOBAL CONTEXT= lelcano/elcano in/zonas in/ari63-2014-montes-belgrade-crossroads-serbian-russian-relationsukraine-crisis

Zuleva, M. (2013). Chinese firms invest in emerging markets energy for EU toehold. Reuters. http://www.reuters.com/article/2013/06/11/energy-balkans-china-idUSL5NOEN1CF20130611) 